\title{
The current tendencies of tax regulations of tncs' investment activity
}

\author{
Y. Shevchenko \\ Department of International Finance, SHEE “Kyiv National Economic University named after Vadym Hetman” \\ Corresponding author.E-mail: shevchenko-julia@ukr.net
}

Paper received 21.11.17; Revised 26.11.17; Accepted for publication 28.11.17.

https://doi.org/10.31174/SEND-NT2017-148V16-06

Abstract. The research is devoted to the main problems concerning current situation in tax regulation of TNCs. Current conditions of the operation of TNCs are disclosed in the paper, taking into account the tax burden that exists in each host country. It shows the main tax rates in some countries that are related to sustainable development in the context of each component. The main analysis of tax regulation and the consequences for the investment of TNCs is provided. The article provides a list of conditions relating to tax regulation in host countries and their impact on the investment behavior of TNCs. The paper provides advice that should be used to build an investment strategy for TNCs. The conclusions regarding further tax regulation of investment activity of TNCs with determination of tax rates and reduction of tax evasion are determined.

Keywords: investments, investment behaviour, international investment, tax, tax evasion, TNCs.

Introduction. Under current conditions, TNCs are increasingly developing strategies for their future operations and investment activities, not only in the context of the law environment, but also in financial regulators, one of which is taxation indifferent host countries and in the parent company.

Recently, the issue of taxation of transnational corporations has caused sharp controversy and significant criticism of society. Taxation of corporate profits is the main regulator of their activities and ensuring the revenue of the state budget of the host countries. Also, tax regulations are set by each country in the framework of its fiscal policy and international activities. In the global turbulent environment, changes are constantly taking place regarding the international taxation of TNCs and other legal entities. These tendencies make TNC management personnel adjust their own corporate and investment strategies. But with the spread of the concept of sustainable development, tax regulation began to affect the environment. Such conditions form the need for a broader study of the problem of tax regulation of investment activities of TNCs.

The analysis of the latest researches and publications. Many foreign and domestic scientists such as Henn M. [2], James S. [3], Modigliani F. [4], Palan R. [8], RudenkoSudarieva L.V. [9] and others involve in research and development of the problems of current tendencies of tax regulation in TNCs' investment activity and its impact on investment behaviour in modern global economic environment. The theoretical and practical skills and knowledge are used during these research and deep study of tax regulation that help to reveal some various situations and economic conditions at exact period of time. These results and recommendations create a new need for further research of current tendencies of tax regulations in TNCs' investment activity. So we have a necessity to study this problem more thoroughly and widely for further economic and investment activity.

These researches are based on the theoretical and practical knowledge which is important for the future study and scientific construction. But in result of different changes in the world's economic space, the need of further research of modern investment trends is still remain actual and it is possible to investigate wider investment problems in our economic space and community.

Setting objectives. The purpose of the paper is a thorough research of the current tendencies of tax regulations of TNCs' investment activity and tax environment, which exists in the host countries of TNCs that manage and change TNCs' investment plan and strategy.

Materials and methods. As a result of work, many scientific publications, periodic materials, reports of international organizations, especially OECD, The UNITED NA-
TIONS, Internet resources are used during research. For more thorough study, it were used abstract, comparison and generalization, grouping, logic methods in this research.

Results and discussions. Recently, the issue of taxation of transnational corporations has caused discussions in society. For example, in the UK, protesters seized Starbucks in early 2013, accusing the company of tax evasion. A large number of information and IT companies based in the United States were suspected of not paying virtually any taxes on their profits abroad. In 2011, Argentina accused Glencore, the world's largest tax evasion trader. Also, in 2013, the disclosure of databases on the activities of offshore centers was increasingly causing discontent among the international community.

Then the G20 began studying the problem of tax havens, declaring in 2009 that the era of banking secrecy was over. The result was that, together with the Organization for Economic Cooperation and Development (OECD), they created a black list of tax havens that were soon empty. In 2011, the lists were reinstated again. At the same time, the finance ministers of the G20 countries are once again trying to solve the problem with offshore centers, and in the course of 2013, some preliminary decisions were made to intensify efforts in the field of taxation of TNCs. In turn, the OECD issued its Addressing Base Erosion and Profit Shifting report illustrating aggressive tax evasion methods (OECD 2013). And in order to eliminate these methods, the OECD has presented an action plan "Action Plan on Erosion and Profit Shifting", which will be approved by Heads of State [2].

This plan provided for the provision of domestic and international instruments aimed at better harmonization of the tax law on the basis of an in-depth analysis of the most vulnerable sectors of the economy in order to provide concrete solutions for the transition of international standards to the current global business environment (avoidance of double taxation, dispute settlement through arbitration)

In our opinion, tax regulators of investment activity of TNCs can both restrain investment and stimulate by differentiating tax rates, objects of taxation in host countries.

But today, and in our opinion, tax havens will exist in the future, where TNCs will be able to reduce tax rates by simply choosing a country or island that are offshore centers.

Offshore is a consequence of globalization and turbulent financial environment, as TNCs are trying to invest their own resources with the lowest risks and profits.

In general, according to the OECD, tax havens are jurisdictions that allow companies and individuals to avoid taxes. Such a deviation may be illegal, but there are also legal methods that are usually used by international firms [7].

In his book, "Tax Shelter: How Globalization Works," 
Ronen Palan, Richard Murphy and Christian Chavagne point out: "There is no generally accepted definition of tax shelter. It is important to note that there is often a common practice that forms a tax haven, and they can to some degree exist in any country in the world. In this case, it is often more appropriate to talk about the harmful practices of the tax harbor. And the question arises why there are tax havens in some countries, and in others there is no "[7].

Taxation plays a key role in regulating the activities of TNCs and is a source of revenue for the budgets of host developing countries. But investors, countries and international organizations are forced to develop an extensive tax system. First and foremost, the investment behavior of TNCs will be affected by the corporate tax, or as the profit tax is called.

In the field of taxation of corporations, scientists such as: Merton Miller and Franco Modigliani were involved. Their development was the knowledge of capital in their work "Capital Expenditure, Corporate Finance and Investment Theory". The tax in this crop acted as costs that increase the value of the corporation. That is why the ideal corporation is based on the absence of taxes as such. In turn, the scientists concluded that the taxes and capital structure of the corporation does not affect the value of the company, if there is a perfect organization of the stock market [5].

Further, economists improved their own theory, which indicated that the cost of equity capital of a corporation that takes financial resources from external sources is equal to the sum of equity value of a similar, ie income and level of risk, corporation that uses only its own funds and premiums for a risk that is defined as the product of the difference in the values of the value of own and borrowed capital to finance the independent financial corporation by the value of the coefficient of financial leverage. That is, when the taxes are absent, the value of the corporation will not depend on the capital structure of the corporation itself [6].

It is in the taxation of corporations that they are a kind of expense that is deducted from the corporation's profit. Therefore, in our opinion, this situation confirms that taxation is a regulator of corporations, as well as investment, reducing the share of investments themselves.

Also, according to F.Modigliani and M.Miller in later revisions, the use of resources from external sources leads to an increase in the cost of the organization due to the deduction of interest on loans from the corporate profit tax, which will result in an increase in operating profit [6].

Therefore, the choice of corporation tax rates is significant for TNC management personnel, since larger taxes reduce the share of investment in the host country. Through its worldwide activities, TNCs can choose and analyze the investment climate of the host country, which includes local taxes levied on affiliates and subsidiaries. But within the framework of the concept of sustainable development, there was a concept such as "environmental tax", which involves deductions for environmental protection.

In the future, regulation through environmental taxes will gain increasing importance not only in highly developed countries, but also in developing countries. This trend will be due to the placement of TNCs' own subsidiaries and affiliates in these countries as full partners in investment projects.

For the host country, today the percentage of income in the host country's budget is not high at an average of 1-3\% of GDP. The main areas of environmental tax are taxation in the areas of energy, transport, air pollution and the use of natural resources, as shown in Table 1.
Table 1. Tax rates related to the environmental sector in some countries in $2015, \%$ of GDP

\begin{tabular}{|l|c|c|c|c|}
\hline \multicolumn{1}{|c|}{ The name of tax } & $\begin{array}{c}\text { Energy } \\
\text { tax }\end{array}$ & $\begin{array}{c}\text { Tax on } \\
\text { transport }\end{array}$ & $\begin{array}{c}\text { Air } \\
\text { pollution } \\
\text { tax }\end{array}$ & $\begin{array}{c}\text { Tax on the } \\
\text { use of } \\
\text { natural } \\
\text { resources }\end{array}$ \\
\hline Austria & 2 & 3 & 4 & 5 \\
\hline Belgium & 1,53 & 0,86 & - & 0,01 \\
\hline Bulgaria & 1,25 & 0,7 & - & - \\
\hline The UK & 2,55 & 0,29 & - & - \\
\hline Greece & 1,82 & 0,58 & 0,06 & 0,02 \\
\hline Denmark & 2,95 & 0,78 & 0 & 0 \\
\hline Estonia & 2,22 & 1,54 & 0,14 & 0,09 \\
\hline Ireland & 2,43 & 0,06 & 0,22 & 0,05 \\
\hline Iceland & 1,17 & 0,73 & 0,02 & - \\
\hline Spain & 1,19 & 0,4 & 0,15 & 0 \\
\hline Italy & 1,58 & 0,24 & 0,07 & 0 \\
\hline Cyprus & 2,76 & 0,59 & 0,04 & 0 \\
\hline Latvia & 2,29 & 0,68 & 0 & 0,01 \\
\hline Lithuania & 2,08 & 0,53 & - & - \\
\hline Luxembourg & 1,67 & 0,05 & 0,04 & 0,06 \\
\hline Malta & 1,69 & 0,14 & - & - \\
\hline The Netherlands & 1,49 & 1,17 & 0,24 & 0 \\
\hline Germany & 1,89 & 1,03 & - & - \\
\hline Norway & 1,59 & 0,32 & 0 & 0 \\
\hline Poland & 1,31 & 0,96 & 0,07 & 0,03 \\
\hline Portugal & 2,27 & 0,21 & - & - \\
\hline Romania & 1,78 & 0,63 & 0 & 0,02 \\
\hline Serbia & 2,19 & 0,23 & 0 & 0 \\
\hline Slovakia & 3,58 & 0,29 & - & - \\
\hline Slovenia & 1,5 & 0,18 & 0,09 & 0 \\
\hline Hungary & 3 & 0,46 & 0,37 & 0,08 \\
\hline Finland & 1,94 & 0,45 & - & - \\
\hline France & 1,99 & 0,88 & 0,04 & 0,01 \\
\hline Croatia & 1,78 & 0,27 & 0,12 & 0,01 \\
\hline $\begin{array}{l}\text { The Czech Repub- } \\
\text { lic }\end{array}$ & 2,57 & 0,84 & 0 & 0,69 \\
\hline Sweden & 1,94 & 0,14 & 0,02 & 0 \\
\hline EU & 1,74 & 0,45 & 0,03 & 0 \\
\hline Eurozone & 0,45 & 0,48 & - & - \\
\hline
\end{tabular}

Such taxes correct the use of natural resources and reduce the amount of $\mathrm{CO} 2$ emissions into the atmosphere. For TNCs, they are certainly costs, but for the host country, there are revenues that go for environmental protection.

But not only environmental taxes transform the investment behavior of TNCs, but also international instruments that oblige the parties to reduce their emissions to the atmosphere. For example, in accordance with the Kyoto Protocol to the United Nations Framework Convention on Climate Change 1997, the countries that have acceded to this treaty should implement policies and measures in accordance with their national circumstances such as: improving energy efficiency in relevant sectors national economy; protection and improvement of the quality of greenhouse gas sinks and stores not regulated by the Montreal Protocol, taking into account their obligations under relevant international environmental agreements; promote the spread of rational methods of forestry, afforestation and reforestation on a stable basis; encouraging sustainable and sustainable agriculture in the context of taking into account the peculiarities of climate change; conducting research, developing, promoting the widespread use and introduction of new and renewable forms of energy, carbon dioxide absorption technologies and advanced state of the art environmentally sound technologies; the gradual reduction or elimination of market imbal- 
ances, fiscal incentives, exemptions from taxes and duties and subsidies that are contrary to the objectives of the Convention in all sectors that are sources of greenhouse gas emissions and the application of market mechanisms and other measures to protect the environment [4].

But tax regulation of environmental protection affects only one aspect of the concept of sustainable development. In a turbulent financial market of TNCs, there are certain problems with avoiding double taxation, since, in our opinion, investment resources, which decrease in proportion to the increase in corporation tax rates, are lost.

But in different countries, the avoidance of double taxation occurs differently. For example, reduction of the tax burden on TNCs is possible through tax privileges and loans. Tax privileges in most countries relate to dividends, that is, for owners of TNC shares, profits remain stable, but resources are reduced to accommodate investment. It follows from the conclusion that host countries receive less investment [3].

In our opinion, the use of tax credits for the investment of TNCs in the host country will be more acceptable. This is due to the fact that the parent company will receive compensation from the corporation from a subsidiary or subsidiary located in the receiving country. The effectiveness of the tax credit is reflected in the consolidated financial statements based on the results of all divisions.

In turn, for Ukraine as a host country, future TNC investments need to improve tax legislation in terms of TNCs regulation and transfer pricing problems.

For example, according to S. James and K. Nobes, the impact of taxation as a financial regulator focuses on the expected return on investment with varying degrees of risk, capital supply and asset prices. Interesting and relevant today is that some of the investments of the corporation are used to return for the return of tax liabilities available for other investments [8].

Taxing stimulates investment at the same time and reduces the amount of investment in host countries. Incentives for investors of any level, whether TNCs or individuals, show what exactly attract investments to the country.

The investment behavior of TNCs depends on the current conditions of the development of the international taxation system. Globalization and financial crises have caused serious imbalances in the structure of the financial system of TNCs [9]. The problem of taxation of affiliate and subsidiaries' income is precisely the difference in tax rates, the difference between the tax systems of the host countries. There is a discrepancy in establishing a single tax on all transactions conducted by TNCs. The main trends in investment behavior will also be [10]:

- an increase in the number of information products due to the proliferation of the digital economy and the problem of the definition of the object and the tax rate;

- the possibility of concluding global trade and investment agreements between countries and regional entities;

- competition between protectionist policies and freetrade policies that differentiate tax rates;

- implementation of the OECD Plan "Addressing Base Erosion and Profit Shifting" (BEPS);

- tax harmonization;

- increase of environmentally safe means of production and complication of their depreciation due to high investment resources;

- tax competition in establishing corporate tax rates in host countries.

Conclusions. Analyzing the current tendencies of tax regulation of TNCs' investment activity and different tax theories, it is possible to draw the following conclusions:

- ecological tax is a new thing in the global economic environment that create opportunities for the host countries in providing safe and good politics of protecting environment but it has a lot of discussions;

- many scientists studied problems of tax regulation and its influence on corporate and countries' strategies;

- existence of constant discussions which are concerned implementing tax plans and providing the limit of double tax systems.

\section{Data of (2017) Retrieved}

http://appsso.eurostat.ec.europa.eu/nui/setupDownloads.do.

from

2. Henn M. (2013). Tax Havens and the Taxation of Transnational Corporations. Friedrich Ebert Stiftung. 1-17.

3. James S. (2014). Economics of Taxation 2013/14. Paperback. 1250.

4. Kyoto protocol to the United Nations Framework Convention on climate change. (1997). Retrieved from https://unfccc.int/resource/docs/convkp/kpeng.pdf.

5. Modigliani, F., Miller, M. Corporate Income Taxes and the Cost of Capital: A Correction. American Economic Review. - 1963. Vol. 53, pp. 432.

6. Modigliani, F., Miller, M. (1958) The cost of Capital, Corporate view. Vol. 48, pp.261-297.

7. OECD. (2013). Addressing Base Erosion and Profit Shifting. Retrieved from http://www.oecd.org/tax/addressing-baseerosion-and-profit-shifting-9789264192744-en.html.

8. Palan R. (2009). Tax Havens How Globalization Really Works. Cornell University Press. Cornell Studies in Money. 1-280.

9. Rudenko-Sudarieva L., Krysiuk R Modern factors in the development of international investment / L. Rudenko-Sudarieva., R. Krysiuk // The practical science edition "Independent AUDITOR”.- 2015.- №14 (IV).- P.27-36.

10. The Global Risks Report 2017. (2017). Retrieved from: https://www.weforum.org/reports/the-global-risks-report-2017.

\section{Современные тенденции налогового регулирования инвестиционной деятельности тнк}

\section{Ю. А. Шевченко}

Аннотация. Исследование посвящено основным проблемам текущей ситуации в налоговом регулировании ТНК. Существующие условия функционирования ТНК раскрыты в работе с учетом налогового бремени, которое существует в принимающей стране. Показаны основные налоговые ставки в некоторых странах, которые связаны с устойчивым развитием в контексте каждого компонента. Предоставлен основной анализ налогового регулирования и последствия для инвестиционной деятельности ТНК. В статье представлен перечень условий, касающихся налогового регулирования в принимающих странах и их влияние на инвестиционное поведение ТНК. В работе содержатся рекомендации, которые следует использовать для построения инвестиционной стратегии ТНК. Определены выводы относительно дальнейшего налогового регулирования инвестиционной деятельности ТНК с определением налоговых ставок и уменьшением уклонения от уплаты налогов.

Ключевые слова: инвестиции, инвестиционное поведение, международные инвестиции, налоги, уклонение от уплаты налогов, THK. 